\title{
Spectral photosynthesis, quantum yield and blue- green light enhancement of productivity rates in the diatom Chaetoceros gracile and the prymnesiophyte Emiliania huxleyi
}

\author{
Oscar Schofield ${ }^{1}$, Robert R. Bidigare ${ }^{2}$, Barbara B. Prézelin ${ }^{1}$ \\ ${ }^{1}$ Department of Biological Sciences and Marine Science Institute, University of California, Santa Barbara, California 93106, \\ USA \\ ${ }^{2}$ Geochemical and Environmental Research Group, Department of Oceanography, Texas A \& M University, College Station, \\ Texas 77843, USA
}

\begin{abstract}
The photosynthetic properties of white and blue-green light grown cultures of a diatom, Chaetoceros gracile, and a prymnesiophyte, Emiliania huxleyi, were compared. The aim of the study was to quantify chromaticity effects on the spectral properties of chromophytes which significantly impact bio-optical predictions of in situ primary production. The comparisons emphasized the spectral dependency of cell pigmentation, absorption, quantum yield and rates of photosynthesis. Concentrations of chlorophylls and carotenoids were similar for the white light cultures of C. gracile and $E$. huxleyi. While the absorption spectra for the chromophytes were similar, E. huxleyi exhibited a higher quantum efficiency and hence a higher photosynthetic rate, than C. gracile. The pattern of blue-green light adaptation was quite distinct for the 2 phytoplankters. The diatom exhibited little change in pigmentation, but relative quantum yield increased slightly as did overall rates of photosynthesis. In the prymnesiophyte, total cell pigmentation was reduced by half, lowering cell absorption while increasing in situ chlorophyll-specific rates of photosynthesis. Carbon action spectra were made with and without background blue-green light in order to assess the potential errors produced by restricted 'Emerson enhancement effects' which are inherent in the measurement of photosynthetic action spectra. Rates of photosynthesis increased 17 to $36 \%$ when enhancement effects were taken into account. These direct measures of photosynthesis were in good agreement with bio-optical model predictions based on the spectral properties of chromophytes.
\end{abstract}

\section{INTRODUCTION}

A physiologically based bio-optical model has been developed to predict phytoplankton productivity from measurements of spectral irradiance, pigmentation and testable assumptions regarding cell absorption and quantum yield (primary production/quanta absorbed) (Bidigare et al. 1987, Prézelin et al. 1988, Smith et al. 1990). Variants of this spectral model have been applied to one station in the Sargasso Sea during a spring diatom bloom to derive estimates of the daily production rate (Bidigare et al. 1987) and to 3 frontal stations off the coast of California to derive instantaneous, diurnal and daily rates of production (Smith et al. 1990). In both instances, the model was specifically constructed and applied to chromophytic (chlorophyll [Chl] $c$ containing) phytoplankton communities domi- nated by diatoms and prymnesiophytes. In the Sargasso Sea application, model parameters used to estimate the quantum yield were wavelength $(\lambda)$-independent and held constant while the photosynthetic potential $\left(\mathrm{P}_{\max }\right)$ was a predicted variable. The agreement between model estimates and radiolabelled measurements increased when the model was spectrally recast for its application to data from off the California coast (Fronts '85) (Prézelin et al. 1988, Smith et al. 1990), where quantum yield was estimated using $\lambda$-dependent photosynthesis-irradiance (P-I) parameters which varied with depth and time of day. With the California data there was agreement within $20 \%$ between ${ }^{14} \mathrm{C}$ measurements and estimates from the spectral model.

The model recognizes the adaptability of algal pigmentation which occurs in all groups of phytoplankton and provides a mechanism for discriminating the con- 
tribution made to algal absorption by both photosynthetic and nonphotosynthetic pigments. Further, the model makes use of defined relationships between photosynthesis, quantum yield, and photosynthetically absorbed radiation $\left(Q_{\text {phar }}\right)$. Such assumptions about the magnitude and sources of variability in optical parameters can and are being inversely tested for all size classes and spectral groups of phytoplankton. The present study is part of this ongoing effort to further identify and quantify the sources and magnitude of the variability in light-dependent spectral properties of phytoplankton which influence bio-optical estimates of primary productivity. Working with a representative coastal diatom and an oceanic prymnesiophyte, the present study documents (1) the effect of blue-green vs white light illumination on pigmentation, absorbance and photosynthesis $s_{i}(2)$ blue-green light photosynthetic enhancement effects on carbon (C)-action spectra and spectral quantum yield; and (3) a predictive linkage between directly measured production via PAR-averaged P-I parameters, $\lambda$-dependent $C$-action spectra, and spectral models of productivity. Estimates of production derived from the model were in good agreement with directly measured values provided that spectral irradiances were adequately defined and that measured maximum quantum yield was used in model calculations, rather than the theoretical upper limit $(0.1$ mol C $\operatorname{Ein}^{-1}$ ). These results support the view that spectral components used to probe algal photosynthesis in situ are mechanistically linked and that these links provide a means by which the spectral properties of algae can be used as proxy measures of productivity.

\section{MATERIALS AND METHODS}

Growth conditions. Unialgal stocks of the coastal diatom Chaetoceros gracile (clone SOLCHAET) and the oceanic prymnesiophyte Emiliania huxleyi (clone BT6) were obtained from the Provasoli-Guillard Center for Culture of Marine Phytoplankton at the Bigelow Laboratory for Ocean Sciences, Maine, USA. Cultures of C. gracile and E. huxleyi were grown at $18^{\circ} \mathrm{C}$ in 2.81 Fernbach flasks containing 1.51 of $\mathrm{f} / 2+\mathrm{Si}$ and $\mathrm{f} / 2$ seawater media respectively (Guillard \& Ryther 1962). Replicate cultures were grown under $50 \mu \mathrm{Ein} \mathrm{m}^{-2} \mathrm{~s}^{-1}$ of constant white light (WL) (20W GE F20T12-CW fluorescent lamps filtered through neutral density cheeseclath) and blue-green light (BG) (white light through a single layer of Lee polyester \#118 photographic filter). The spectral outputs of growth illumination have been defined elsewhere (Bidigare et al. 1989). Prior to experimentation, cells were light acclimated for several generations by serially diluting log phase populations with fresh media. All experimental runs were carried out at the same time of the day to minimize the error associated with any of the endogenous rhythms within the cultures. Cells were microscopically enumerated on a hemacytometer and their linear dimensions determined with an ocular micrometer. Cell volumes were estimated from linear dimensions (Kovala \& Larrance 1966), assuming a cylindrical cell shape for $C$. gracile and a spherical cell shape for $E$. huxleyi.

Pigment analyses. Ten $m l$ aliquots of culture were filtered in triplicate onto $25 \mathrm{~mm}$ GF/F filters and extracted in $5 \mathrm{ml}$ acetone for $48 \mathrm{~h}\left(-20^{\circ} \mathrm{C}\right)$. Clarified extracts were analyzed by reverse-phase HPLC using a Spectra Physics Model SP8700 liquid chromatograph equipped with a Radial Pak $C_{18}$ column $(0.8 \times 10 \mathrm{~cm}$, 5 um particle size) at a solvent flow rate of $6 \mathrm{ml} \mathrm{min}^{-1}$. Pigment peaks were identified, quantified (ng pigment $\mathrm{ml}^{-1}$ culture), and corrected for any pigment isomerzations during extraction according to the procedures outlined by Bidigare (1989).

Absorption spectra. Dilute cell suspensions were sampled directly from culture flasks and serially diluted with fresh media $(1: 1,1: 2,1: 4,1: 8)$ for measurements of spectral absorption coefficient. Absorption spectra were measured with a DW-2a spectrophotometer, with samples referenced against similarly diluted cell filtrates (Boucher unpubl.). Opal glass was inserted between the sample/reference cuvettes, and a beam scrambler directed transmitted light to the photomultiplier. The spectra presented here represent whole cell absorption where multiple-scattering was minimized, as evidenced by the linearity of the dilution series and the added criteria that all cell suspensions have an optical thickness less then 0.05 (>95\% transmittance) (Morel et al. 1987). All absorption data were transferred from the Aminco DW-2a spectrophotometer to a Zenith 248 computer for storage and subsequent data analyses.

Calculations of photosynthetically absorbed radiation. Qphar, the photosynthetically absorbed radiation (Ein $\mathrm{m}^{-3} \mathrm{~h}^{-1}$ ) for each culture was calculated as a product of culture absorption $\left(\mathrm{a}(\lambda) ; \mathrm{m}^{-1}\right)$ and the spectral

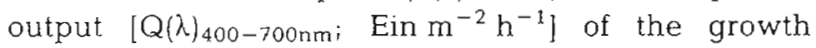
irradiance (Smith et al. 1990):

$$
Q_{\text {phar }}=\int_{400 \mathrm{~nm}}^{700 \mathrm{~nm}} \mathrm{Q}(\lambda) \mathrm{a}(\lambda) \mathrm{d} \lambda
$$

Room temperature fluorescence excitation spectra. Quanta-corrected excitation spectra of photosystem PSII chl a fluorescence at $680 \mathrm{~nm}\left(\mathrm{~F}_{680}\right)$ and $730 \mathrm{~nm}\left(\mathrm{~F}_{730}\right)$ (Neori et al. 1988) were measured using a SLM-Aminco SPF-500C operating in its ratio mode. For $F_{680}$ spectra, bandwidths for excitation and emission were 4 and $10 \mathrm{~nm}$ respectively. For $F_{730}$ spectra, bandwidths for excitation and emission were 4 and $5 \mathrm{~nm}$ respectively. 
Spectra were acquired, stored and analyzed with an attached AT-compatible microcomputer using SLM spectral analysis software. As observed with other algae (Neori et al. 1988), the shape of the $F_{680}$ and $F_{730}$ excitation spectra were similar enough over the wavebands that both measurements could be resolved without any throughput from the exciting light (i.e. below about $620 \mathrm{~nm}$ for the $\mathrm{F}_{680}$ measurements). Since the $F_{680}$ signal:noise ratio was much higher than that of $F_{730}$, the $F_{680}$ spectra were used to define the shape of excitation spectra below $620 \mathrm{~nm}$ and a matching of the $F_{680}$ vs $F_{730}$ spectra was used to define the proportional changes in spectral shape at wavelengths near the red end of the visible spectrum. When compared to cellular absorption and normalized at $680 \mathrm{~nm}$, a relative measure of wavelength-dependency of PSII energy transfer efficiency was derived and here expressed as $F_{680}(\lambda) /$ $\mathrm{a}(\lambda)$.

Carbon uptake measurements. In each experimental run, $175 \mathrm{ml}$ of culture was inoculated with $\mathrm{NaH}^{14} \mathrm{CO}_{3}$ (final activity ca $0.45 \mu \mathrm{Ci} \mathrm{ml} l^{-1}$ ) and $1 \mathrm{ml}$ aliquots were dispensed into 140 acid-washed glass scintillation vials. Eighty-six vials were used for determination of C-action spectra; 46 vials for determination of white and blue-green photosynthesisirradiance (P-I) relationships (see below); and 4 for dark and 4 for time zero $\left(\mathrm{t}_{0}\right)$ samples. Incubation temperature $\left(18^{\circ} \mathrm{C}\right)$ and time $(45 \mathrm{~min})$ were identical for all samples, with reactions being stopped by the addition of $1 \mathrm{ml}$ of glacial acetic acid:methanol mix (1:30 GAM). After heat drying, $1 \mathrm{ml}$ of double deionized water was added to resolubilize the salts. Nine $\mathrm{ml}$ of Liquiscint scintillation cocktail was added and the samples were counted on a LKB 1217 Scintillation Counter. Quenching was corrected using an external standard and all samples were corrected for uptake in the $t_{0}$ controls. Dark rates were only slightly higher then $t_{0}$ controls (corrected dark rates averaged $<5 \%$ of the light rates). Dark-corrected photosynthetic rates were calculated as described in Strickland \& Parsons (1972).

White and blue-green P-I relationships were determined simultaneously on white vs blue-green photosynthetrons which have been previously described (Prézelin et al. 1989). From curve-fitted P-I data, photosynthetic parameters and their error estimates were derived. The P-I parameters included $\mathrm{P}_{\max }$ (the light-saturated rate of photosynthesis); alpha (the light-limited rate of photosynthesis) and $\mathrm{I}_{\mathrm{k}}\left(=\mathrm{P}_{\max } /\right.$ alpha, an approximate estimate of the minimum irradiance required to light-saturate rates of photosynthesis). Estimates of the standard deviations for the P-I parameters were calculated using the procedures described by Zimmerman et al. (1987). Non-linear curve fits for P-I data were calculated using the
SIMPLEX method of Caceci \& Cacheris (1984). In situ photosynthetic performance $\mathrm{P}_{1}$ was calculated as

$$
P_{1}=P_{\max } \tanh \left(I / I_{k}\right)
$$

where I $=$ in situ or culture irradiance (Smith et al. 1987).

C-action spectra were measured on modified spectral photosynthetrons (Lewis et al. 1985) detailed by Boucher et al. (1990). Vials were placed over a range of light-limiting spectral irradiances arrayed for 13 different $25 \mathrm{~nm}$ bandwidths centered between 400 and $700 \mathrm{~nm}$. For enhanced C-action spectra measurements, additional blue-green background illumination was provided by Lee \# 118 filtered $500 \mathrm{~W}$ tungsten halogen lamps mounted face-down directly above open incubation vials. The distance between the background lamp and the sample vials could be adjusted in order to vary the intensity of the background light. Following the procedures of Reid et al. (1977), blue-green P-I relationships were determined (see above) prior to the experimental run in order to select a background irradiance about $20 \%$ of $I_{k}$ values, thereby maximizing enhancement effects without light-saturating photosynthesis. For both enhanced and unenhanced Caction spectra, photosynthetic rate was determined as a linear function of spectral irradiance, with the $\lambda$ dependent slope, alpha $(\lambda)[\alpha(\lambda)]$, estimated by linear regression and plotted to show \pm one standard error of the estimate (Lewis et al. 1985). A Student's t-test was used to estimate the statistical significance of enhancement effects. Following procedures of Boucher et al. (unpubl.), estimates of in situ productivity $(P(\lambda)$ ) were derived from $\mathrm{C}$-action spectra and the spectral irradiance of growth illumination $I(\lambda)$ determined in $25 \mathrm{~nm}$ increments across the visible spectrum (400 to $700 \mathrm{~nm}) . P(\lambda) e$ and $P(\lambda) u$ represent the resulting estimates of enhanced and unenhanced photosynthetic performance, respectively, such that

$$
\begin{aligned}
& \mathrm{P}(\lambda) \mathrm{e}=\Sigma[\alpha(\lambda) \text { e } \mathrm{I}(\lambda)] \\
& \mathrm{P}(\lambda) \mathrm{u}=\Sigma[\alpha(\lambda) \mathrm{u} \cdot \mathrm{I}(\lambda)]
\end{aligned}
$$

Quantum yield estimates. Estimates of spectral quantum yield $\phi(\lambda)$ for carbon fixation (mol C fixed per mol quanta absorbed) were calculated in $25 \mathrm{~nm}$ increments by dividing each $\mathrm{C}$-action spectrum by the corresponding phytoplankton absorption spectrum, such that

$$
\phi(\lambda)=\alpha(\lambda) / \mathrm{a}(\lambda)
$$

Errors in the spectral quantum yield estimates were not calculated. Because of the linearity of the absorption data and the reproducibility of the spectral irradiance measurements, most error in $\phi(\lambda)$ is probably associated with the error in the $\alpha(\lambda)$ estimates which are shown in the plots of $\mathrm{C}$-action spectra. 


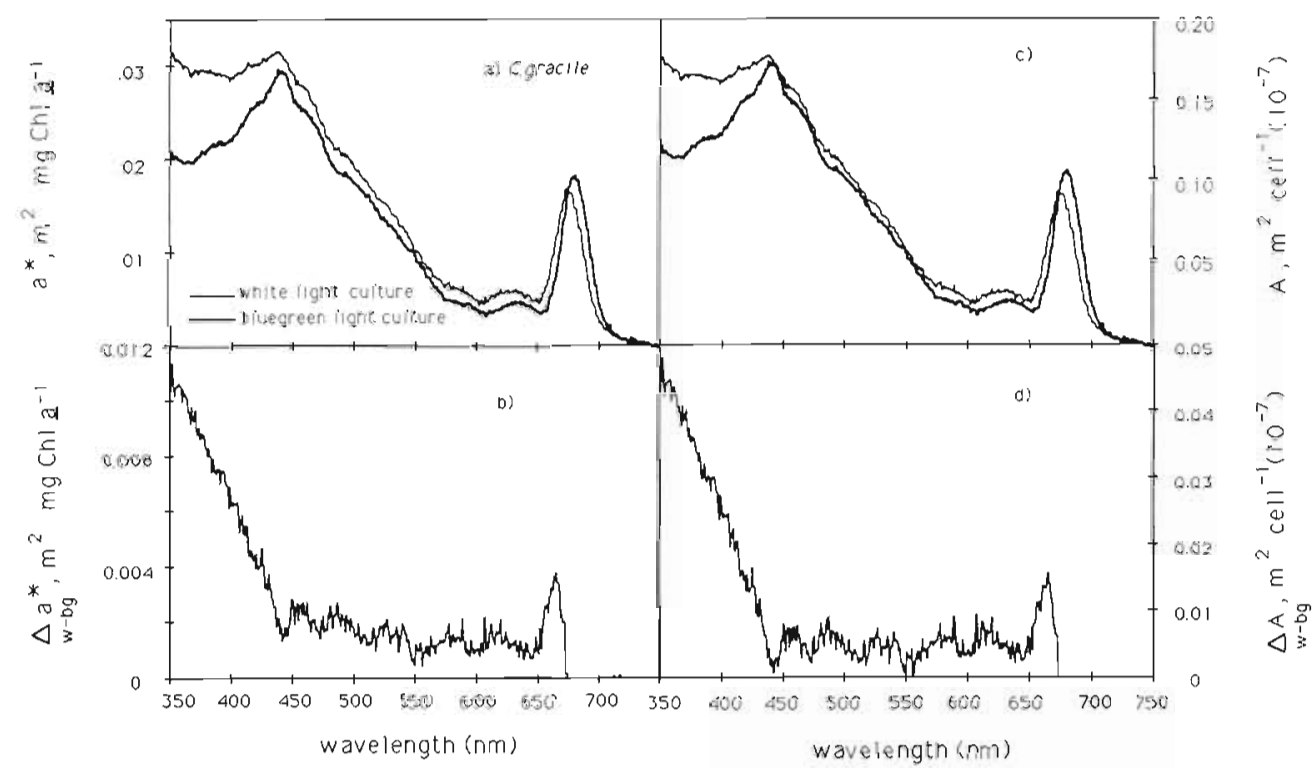

Fig. 1. Chaetoceros gracile. Absorption spectra for white (thin line) and blue-green (bold line) light grown cells. The white-minusbluegreen difference spectrum $\left(\Delta a^{*}\right)$ for the (a) chl-specific absorption spectra ( $\left.a^{\circ}\right)$ is shown in (b). The white-minus-bluegreen difference spectrum for the chl-specific absorption $\left(\Delta \mathrm{a}^{\circ}\right)$ is shown in (c) and the cell-specific absorption $(\Delta \mathrm{A})$ is shown in $(\mathrm{d})$

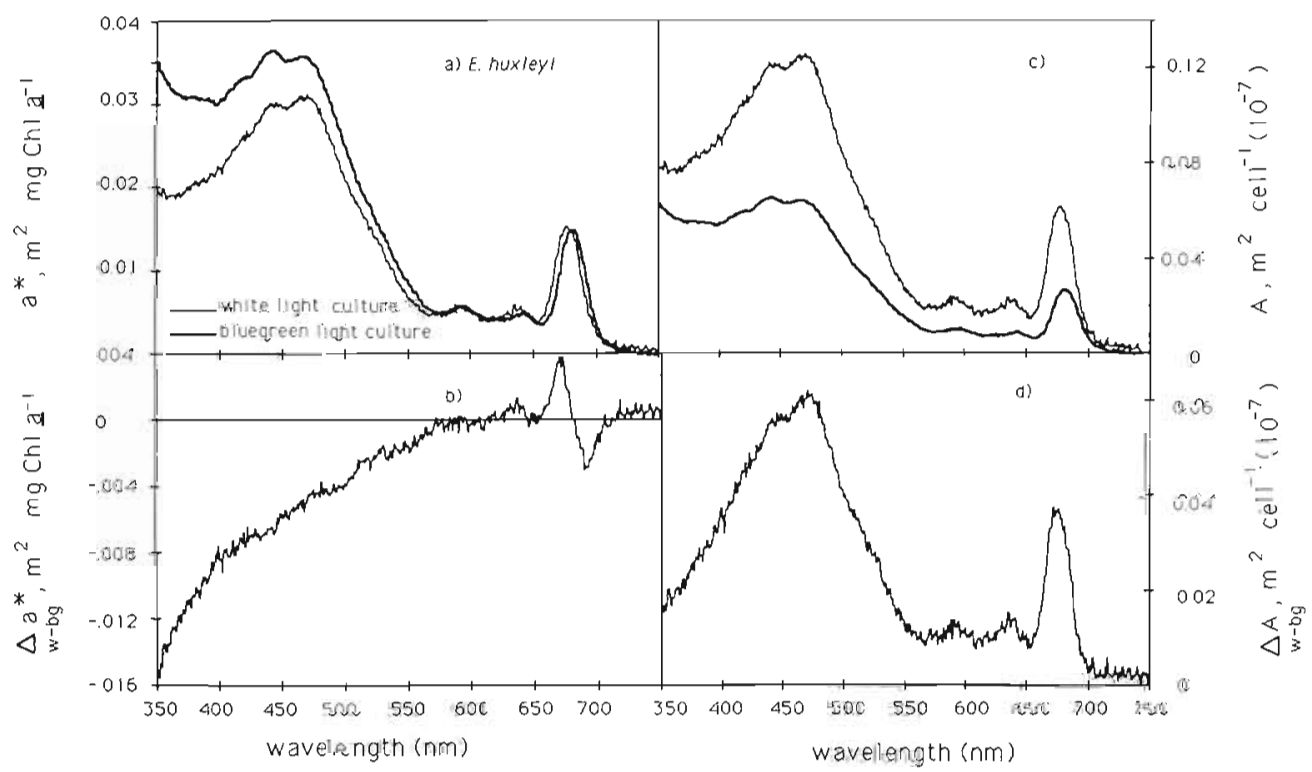

Fig. 2. Emiliania huxleyi. Absorption spectra for white (thin line) and blue-green (bold line) light grown cells. The white-minusbluegreen difference spectrum $\left(\Delta \mathrm{a}^{*}\right)$ for the (a) chl-specific absorption spectra $\left(\mathrm{a}^{*}\right)$ is shown in (b). The white-minus-bluegreen difference spectrum for the chl-specific absorption $\left(\Delta \mathrm{a}^{*}\right)$ is shown in (c) and the cell-specific absorption $(\Delta \mathrm{A})$ is shown in (d)

absorption maximum, which was apparently due to a preferential enrichment of shorter wavelength chl $a$ at the expense of longer wavelength forms of chl a (Fig. 2b); and (5) no difference in the magnitude of the red end chl-specific absorption maximum $\left(0.015 \mathrm{~m}^{2}\right.$ $\mathrm{mg}^{-1} \mathrm{chl}$ a for both WL and BG grown cells). Difference spectra were calculated by subtracting the absorption spectra of BG cultures from WL cultures. The chlspecific difference spectrum for E. huxleyi was nega- tive from 350 to $600 \mathrm{~nm}$ (Fig. 2b). The a ${ }_{675}$ is $30 \%$ lower then values reported by Bricaud et al. (1983).

\section{Photosynthesis-irradiance parameters and unenhanced/enhanced carbon action spectra}

Log phase cells were harvested and P-I determinations were made under both white and blue-green 
incubation light (Tables 2 and 3). Comparison of the results enabled us to determine whether observed differences in photosynthesis reflected short-term chromatic adaptations to the incubation light and/or long-term acclimation to the spectral irradiance of the growth illumination.

For WL grown Chaetoceros gracile, measured rates of the white light chl-specific $P_{\max }$ were half those of the blue-green light $\mathrm{P}_{\max }$ (Table 2). Conversely, BG grown diatoms had a $40 \%$ higher photosynthetic potential when samples were WL incubated. BG light grown cells had significantly higher chl-specific alpha values then WL cells and, unlike $P_{\max }$, were not sensitive to the color of incubation light. Therefore varia- tions in $\mathrm{I}_{\mathrm{k}}\left(\mathrm{P}_{\max } / \alpha\right)$ reflected variations in $\mathrm{P}_{\max }$. The changes in cell-specific P-I parameters (Table 3 ) mirrored those described for chl-specific parameters and their absolute values were used to estimate a photosynthetic rate $\left(P_{\mathrm{i}}\right)$. Such calculations indicated $W L$ and $B G$ cells maintained relatively similar rates of chlspecific photosynthesis. This is because alpha was constant and the cells were light-limited. Finally, comparisons of the $\mathrm{P}_{\mathrm{j}}$ estimates for the diatom cultures indicated that the blue-green cells had a $50 \%$ higher cellular $\mathrm{P}_{\mathrm{I}}$ than that of WL cells.

For Emiliania huxleyi, the chl-specific and cellspecific $\mathrm{P}_{\max }$ did not vary with the growth irradiance or the color of the P-I incubation light (Tables 2 and 3).

Table 2. Chaetoceros gracile and Emiliania huxleyi. Comparison of chl-specific P-I parameters for white and blue-green light (50 $\mu$ Ein $\mathrm{m}^{-2} \mathrm{~s}^{-1}$ ) grown log phase cells, where replicate samples from each culture condition were incubated 45 min under both white and blue-green light conditions. Photosynthetic potential $\left(\mathrm{P}_{\max }\right)$ is expressed as $\mathrm{mg} \mathrm{C} \mathrm{mg} \mathrm{chl} \mathrm{C}^{-1} \mathrm{~h}^{-1}, a$ is the light-limited photosynthetic efficiency [ $\left.\mathrm{mg} \mathrm{C} \mathrm{mg} \mathrm{chl} \mathrm{l}^{-1} \mathrm{~h}^{-1}\left(\mu \operatorname{Ein~} \mathrm{m}^{-2} \mathrm{~s}^{-1}\right)^{-1}\right]$, and $\mathrm{I}_{\mathrm{k}}$ is Pmax/ $\alpha$. Production rates are expressed as mg $\mathrm{C} \mathrm{mg} \mathrm{chl}{ }^{-1}$ $h^{-1}$ and estimates of the standard deviations for the P-I parameters were calculated following procedures described by Zimmerman et al. (1987). Ranges for maximum limits on $\mathrm{P}_{i}$ estimates are shown in parentheses. Detectable wavelengthdependent changes in P-I parameters are printed bold

\begin{tabular}{|c|c|c|c|c|c|c|c|c|}
\hline \multirow{2}{*}{$\begin{array}{l}\text { Organism } \\
\text { Incubation light }\end{array}$} & \multicolumn{4}{|c|}{ White-light grown culture } & \multicolumn{4}{|c|}{ Blue-green light grown culture } \\
\hline & $P_{\max }$ & $\alpha$ & $\underline{I}_{k}$ & $\mathrm{P}_{\mathrm{i}}$ & $P_{\max }$ & $\alpha$ & $\mathrm{I}_{\mathrm{k}}$ & $\mathrm{P}_{\mathrm{i}}$ \\
\hline \multicolumn{9}{|l|}{ C. gracile } \\
\hline White & $\begin{array}{r}2.19 \\
\pm 0.20\end{array}$ & $\begin{array}{r}0.0254 \\
+0.0063\end{array}$ & $\begin{array}{r}86 \\
+\quad 23\end{array}$ & $\begin{array}{c}1.15 \\
(1.02-1.30)\end{array}$ & $\begin{array}{r}3.54 \\
+0.51\end{array}$ & $\begin{array}{r}0.0311 \\
\pm 0.0117\end{array}$ & $\begin{array}{r}114 \\
+\quad 44\end{array}$ & $\begin{array}{c}1.43 \\
(1.24-1.86)\end{array}$ \\
\hline Blue-green & $\begin{array}{r}4.04 \\
\pm 0.37\end{array}$ & $\begin{array}{r}0.0215 \\
\pm 0.0030\end{array}$ & $\begin{array}{r}189 \\
+\quad 34\end{array}$ & $\begin{array}{c}1.04 \\
(0.98-1.15)\end{array}$ & $\begin{array}{r}2.53 \\
\pm 0.14\end{array}$ & $\begin{array}{r}0.0315 \\
\pm 0.0032\end{array}$ & $\begin{array}{r}80 \\
+\quad 8\end{array}$ & $\begin{array}{c}1.40 \\
(1.36-1.51)\end{array}$ \\
\hline $\begin{array}{l}\text { E. huxleyi } \\
\text { White }\end{array}$ & $\begin{array}{r}2.05 \\
\pm 0.07\end{array}$ & $\begin{array}{r}0.0383 \\
+0.0031\end{array}$ & $\begin{array}{r}54 \\
+\quad 4\end{array}$ & $\begin{array}{c}1.49 \\
(1.47-1.52)\end{array}$ & $\begin{array}{r}1.99 \\
\pm 0.08\end{array}$ & $\begin{aligned} & 0.0462 \\
\pm & 0.051\end{aligned}$ & $\begin{array}{r}104 \\
\pm \quad 11\end{array}$ & $\begin{array}{c}2.14 \\
(2.00-2.26)\end{array}$ \\
\hline Blue-green & $\begin{array}{r}2.02 \\
\pm 0.26\end{array}$ & $\begin{array}{r}0.0554 \\
\pm 0.0205\end{array}$ & $\begin{array}{r}36 \\
\pm \quad 11\end{array}$ & $\begin{array}{c}1.78 \\
(1.68-1.81)\end{array}$ & $\begin{array}{r}1.97 \\
+0.08\end{array}$ & $\begin{array}{r}0.0515 \\
\pm 0.0041\end{array}$ & $\begin{array}{r}92 \\
\pm \quad 8\end{array}$ & $\begin{array}{c}2.36 \\
(2.29-2.69)\end{array}$ \\
\hline
\end{tabular}

Table 3. Chaetoceros gracile and Emiliania huxleyi. Comparison of cell-specific P-I parameters for white and blue-green light (50 $\mu$ Ein $\mathrm{m}^{-2} \mathrm{~s}^{-1}$ J grown log phase cells where replicate samples from each culture condition were incubated 45 min under both white and blue-green light conditions. Photosynthetic potential $\left(\mathrm{P}_{\max }\right)$ is expressed as pg C cell ${ }^{-1} \mathrm{~h}^{-1}, \alpha$ is the light-limited photosynthetic efficiency $\left[\mathrm{pg} \mathrm{C}\right.$ cell ${ }^{-1} \mathrm{~h}^{-1}\left(\mu \text { Ein } \mathrm{m}^{-2} \mathrm{~s}^{-1}\right)^{-1}$ l, and $\mathrm{I}_{\mathrm{k}}$ is $\mathrm{P}_{\mathrm{mox}} / \alpha$. Production rates are expressed as pg C cell ${ }^{-1} \mathrm{~h}^{-1}$ and estimates of the standard deviation for the parameters were calculated by following procedures described by Zimmerman et al. (1987). Limits

of $\mathrm{P}_{\mathrm{i}}$ estimates are shown in parentheses. Detectable wavelength-dependent changes in P-I parameters are printed bold

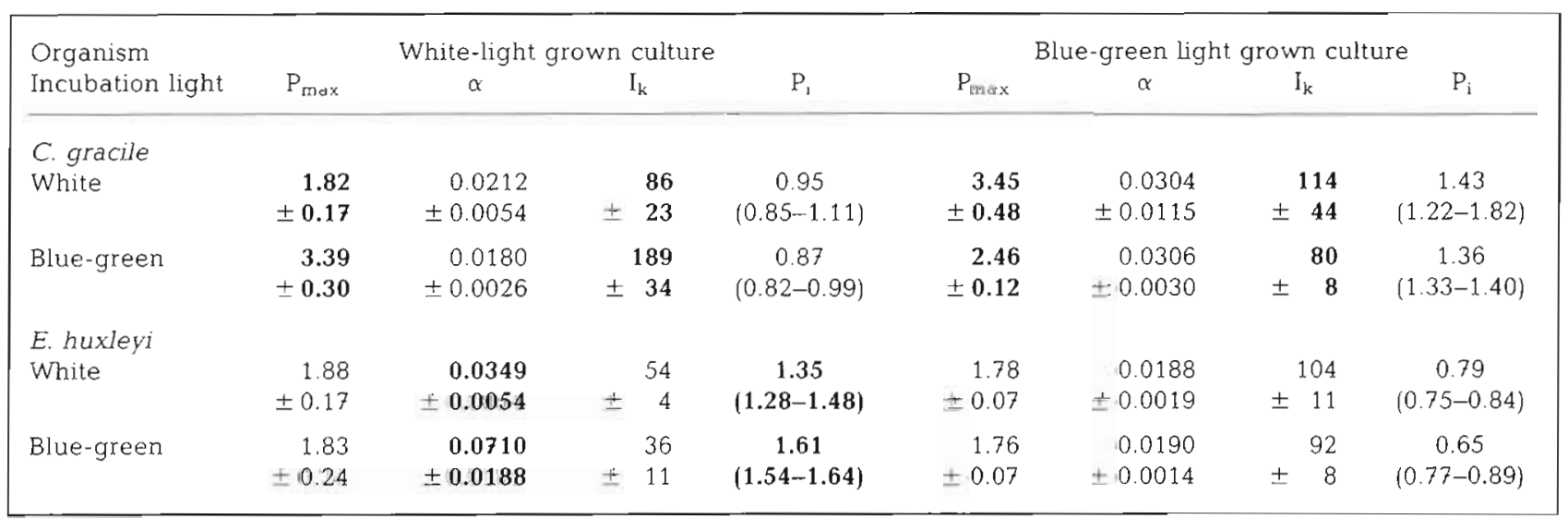


$\mathrm{P}_{\max }$ values were comparable to those measured for $\mathrm{WL}$ Chaetoceros gracile cells. The magnitude of $\alpha$ was dependent on the color of the growth irradiance and P-I incubation light. The $\alpha$ values for WL grown cells under white incubation light were (1) twice the values for BG grown cells incubated under either WL or BG light, and (2) 2-fold higher when incubated under BG light. In contrast with $C$. gracile, fluctuations in $\mathrm{I}_{\mathrm{k}}$ reflected the changes in $\alpha$. The $I_{k}$ for WL grown cells were (1) half those of BG grown cells incubated under either WL or BG P-I light and (2) twice that of WL grown cells exposed to $B G$ light. $P_{i}$ estimates for $W L$ cells were $70 \%$ higher then BG light grown cells. WL grown $E$. huxleyi cells were light-saturated for photosynthesis while the BG cells were light-limited for photosynthesis.

Carbon action spectra $\left(\mathrm{mg} \mathrm{C} \mathrm{mg} \mathrm{chl} \mathrm{ch}^{-1} \mathrm{~h}^{-1}\left[\mu \mathrm{Ein} \mathrm{m}^{-2}\right.\right.$ $\mathrm{s}^{-1} \mathrm{~J}^{-1}$ ) were determined for the BG light grown cultures with (enhanced) and without (unenhanced) background illumination, and are compared in Fig. 3. For

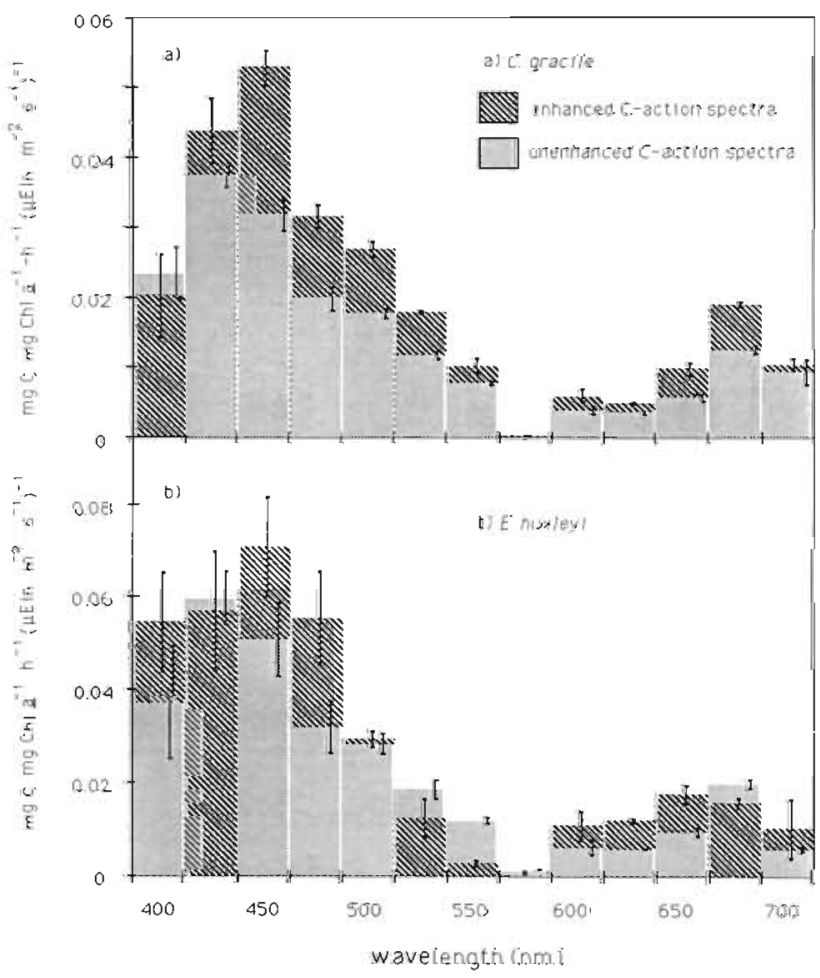

Fig. 3. (a) Chaetoceros gracile; (b) Emiliania huxleyi. Unenhanced stipped and enhanced (diagonal lines) chl-specific Caction spectra for blue-green light grown cells. Vertical lines indicate \pm one standard error for each $25 \mathrm{~nm} \lambda$-dependent $\alpha$ estimate

both clones, the highest $\alpha(\lambda)$ values were measured between 400 and $500 \mathrm{~nm}$ where the absorption of accessory carotenoids and chlorophylls is highest. Background illumination generally increased $\alpha(\lambda)$ val- ues. In Chaetoceros gracile, there was significant enhancement at all $\lambda>425 \mathrm{~nm}$ except for the 575 and $700 \mathrm{~nm}$ wavebands. The greatest enhancement (i. e. 30 to $40 \%$ ) occurred around 440 and $675 \mathrm{~nm}$ where chl a absorption is maximum. Blue-green enhancement of $\alpha(\lambda)$ in Emiliania huxleyi was less evident with significant enhancement at the 475, 625, and $650 \mathrm{~nm}$ wavebands. The largest increases (30 to $40 \%$ ) were noted only in the spectral regions centered near 460 and $640 \mathrm{~nm}$ where in vivo chl $c$ absorptions dominates (cf. Prézelin \& Boczar 1986).

\section{Photosynthetic efficiency and spectral quantum yield}

The enhanced C-action spectra (Fig. 3) were divided by absorption spectra (Figs. 1 and 2) to yield estimates

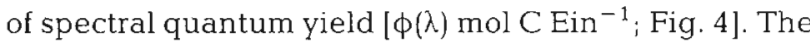

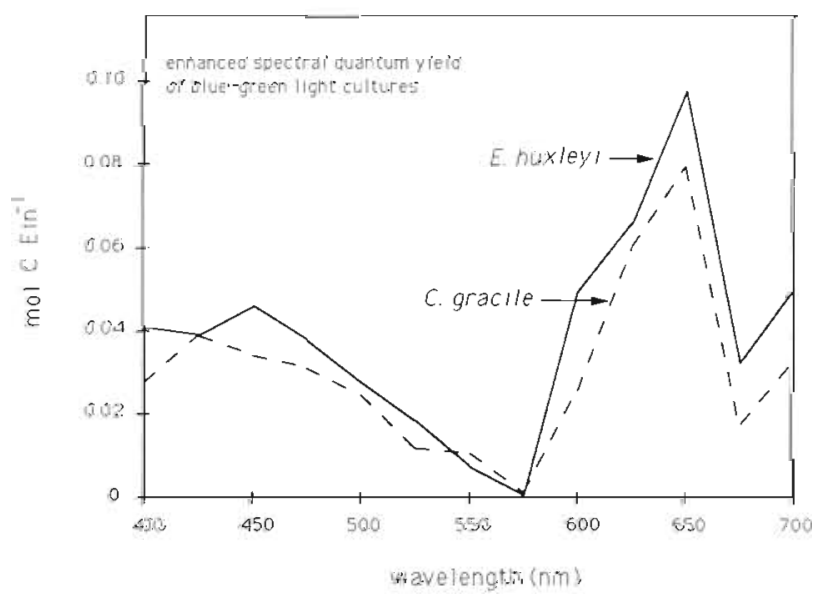

Fig. 4. Chaetoceros gracile and Emiliania huxleyi. Spectral quantum yield $\left[\phi(\lambda), \mathrm{mol} \mathrm{C} \mathrm{Ein}^{-1}\right]$ derived from blue-green light enhanced C-action spectra and directly measured absorption spectra of blue-green light grown cells

spectral dependency of $\phi$ was similar for the diatom and the prymnesiophyte. The quantum yield at the red end of the visible spectrum approached the upper theoretical limit for $\phi(\lambda)$, i. e. 0.080 to $0.125 \mathrm{~mol} \mathrm{C} \mathrm{Ein}^{-1}$ (Emerson \& Lewis 1942). At the shorter red wavebands where chl $c$ absorption predominates, $\phi(\lambda)$ falls to around $0.060 \mathrm{~mol} \mathrm{C} \mathrm{Ein}^{-1}$. Throughout the blue-green region of the visible spectrum, $\phi(\lambda)$ is less than $0.05 \mathrm{~mol}$ C Ein ${ }^{-1}$

For comparison with the estimates of the quantum yield, the relative photosynthetic efficiency of PSII fluorescence excitation was determined by dividing the fluorescence excitation spectra by the absorption spectra, and normalizing at $680 \mathrm{~nm}$ (Fig. 5). Given the dilution controls used to derive both the absorption and fluorescence excitation spectra, the error in the derived 


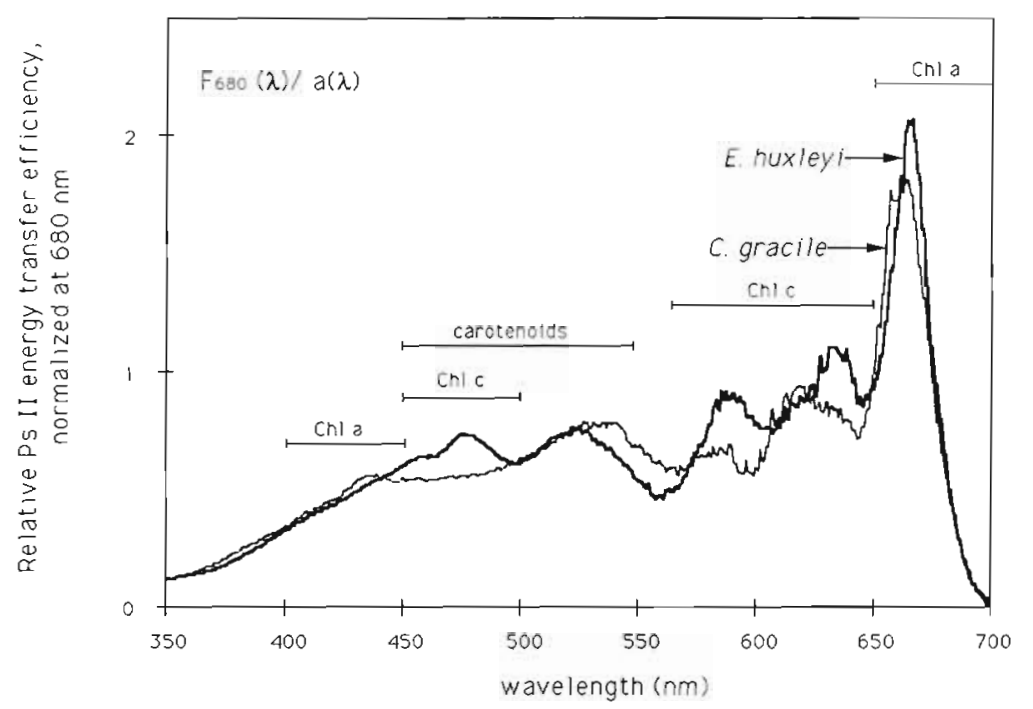

Fig. 5. Chaetoceros gracile and Emiliania huxleyi. Relative wavelength-dependent PSII energy transfer efficiency for blue-green light grown cells, derived by dividing the $\mathrm{F}_{680}$ excitation spectrum by the absorption spectrum with $F_{680}(\lambda) / \alpha(\lambda)$ values normalized at $680 \mathrm{~nm}$ ratio should be correspondingly small and the differences between the spectra should signify real differences in the organization of the photosynthetic pigments around PSII (Prézelin \& Boczar 1986). With the exception of the neglible estimates of $\phi(\lambda)$, at $575 \mathrm{~nm}$ (Fig. 4), the general shape of the PSII efficiency approximated those of spectral quantum yield for carbon fixation. Furthermore, the PSII efficiency spectra indicate that quantum conversion falls off rapidly in the UV-A portion of the visible spectrum (Fig. 5), even while cell absorption remains very high (Figs. 1 and 2)

Finally, when blue-green $\mathrm{C}$-action spectra are combined with knowledge of the blue-green growth illumination, it is possible to describe the wavelength dependency of the photosynthetic activity (Fig. 6). For both clones, unenhanced measurements implied that production was largely driven by $440 \mathrm{~nm}$ light absorbed by chl $a_{i}$ enhanced measurements were required to resolve the added importance of accessory chl $c$ and xanthophyll involvement in promoting in situ rates of production. Considering enhancement effects on spectral photosynthesis, estimates of in situ productivity increased $36 \%$ for Chaetoceros gracile and $17 \%$ for Emiliania huxleyi.

\section{Comparisons between difierent light-dependent estimates of production}

Given the data available, it was possible to compare in situ productivity estimates ( $\mathrm{mg} \mathrm{C} \mathrm{mg} \mathrm{chl} \mathrm{a}^{-1} \mathrm{~h}^{-1}$ ) for BG light grown Chaetoceros gracile and Emiliania huxleyi (Table 4). Hourly productivity rates were derived from blue-green P-I parameters $\left(\mathrm{P}_{\mathrm{i}}\right)$ (Tables 2 and 3), from the total photosynthetic activity measured with unenhanced $\mathrm{C}$-action spectra $[\Sigma \mathrm{P}(\lambda) \mathrm{u}]$ and $\mathrm{C}$-action

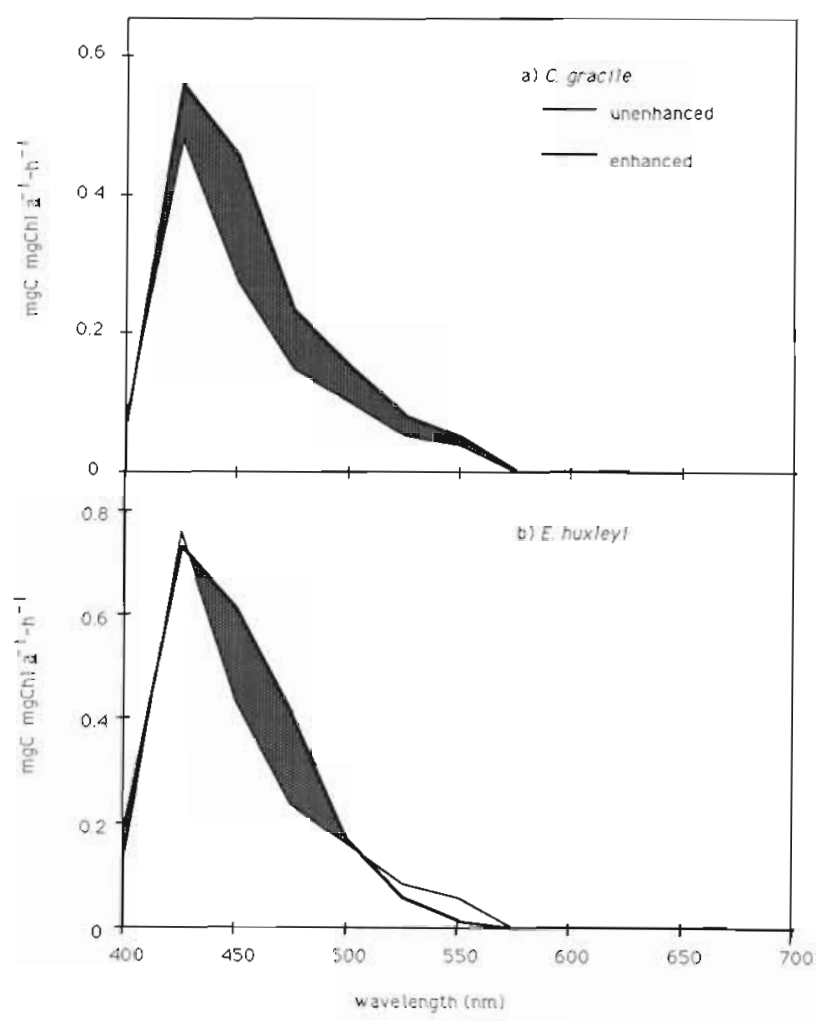

Fig. 6. (a) Chaetoceros gracile; (b) Emiliania huxleyi. Unenhanced (thin line) and enhanced (bold line) $\lambda$-dependent estimates of in situ rates of photosynthesis $\left(\mathrm{mg} \mathrm{C} \mathrm{mg} \mathrm{chl} \mathrm{a}^{-1}\right.$ $\mathrm{h}^{-1}$ ); derived from measurements of $\mathrm{C}$-action spectra and the spectral irradiances of growth illumination. Shaded areas represent enhanced-minus-unenhanced production estimates

spectra enhanced with background illumination $[\Sigma \mathrm{P}(\lambda) \mathrm{u}]$. The values of $\Sigma \mathrm{P}(\lambda) \mathrm{u}$ significantly underestimated $P_{1}$, however there was good agreement between $P_{i}$ and $\Sigma P(\lambda)$ e. Productivity estimates from the bio- 
Table 4. Chaetoceros gracile and Emiliania huxleyi. Comparison of in situ productivity estimates (mg C $\left.\mathrm{mg} \mathrm{chl}^{-1} \mathrm{~h}^{-1}\right)$ for bluegreen light grown cells, where $\mathrm{P}_{1}$ was derived from blue-green $\mathrm{P}$-I parameters; $\Sigma \mathrm{P}(\lambda)$ u from unenhanced $C$-action spectra; $\Sigma P(\lambda)$ e from $\mathrm{C}$-action spectra enhanced with background blue-green illumination; and a spectral model of productivity, where estimated photosynthetically absorbed radiation $\left(Q_{\text {phar }}\right)$ is converted to a C-fixation rate using either directly measured quantum yield ( $\left.\phi\right)$ averaged for over the visible spectrum $\left(\phi_{P_{A} \text { ) }}\right.$ ) or an upper theoretical limit of $\phi=0.1 \mathrm{~mol} \mathrm{C} \mathrm{Ein}^{-1}$

\begin{tabular}{|c|c|c|c|c|c|}
\hline \multirow[t]{2}{*}{ Organism } & \multirow[t]{2}{*}{$\mathrm{P}_{\mathrm{i}}$} & \multirow[t]{2}{*}{$\Sigma \mathrm{P}(\lambda) \mathrm{u}$} & \multirow[t]{2}{*}{$\Sigma P(\lambda) e$} & \multicolumn{2}{|c|}{ PHAR model } \\
\hline & & & & $\bar{\phi}_{P A R}$ & $\phi=0.1$ \\
\hline C. gracile & $\begin{array}{c}1.40 \\
(1.36-1.51)^{a}\end{array}$ & $\begin{array}{c}1.18 \\
( \pm 0.08)^{\mathrm{b}}\end{array}$ & $\begin{array}{c}1.61 \\
( \pm 0.13)^{b}\end{array}$ & 1.70 & 4.50 \\
\hline E. huxleyi & $\begin{array}{c}2.36 \\
(2.29-2.69)^{a}\end{array}$ & $\begin{array}{c}1.88 \\
( \pm 0.25)^{\mathrm{b}}\end{array}$ & $\begin{array}{c}2.20 \\
( \pm 0.40)^{b}\end{array}$ & 2.34 & 5.92 \\
\hline
\end{tabular}

optical model were reasonable when values of $\phi_{\text {PAR }}$ were derived from the average of spectral quantum yield measurements in Fig. 4. The modeling approach which assumes an upper theoretical limit for $\phi$ overestimated production by 2 to 3 -fold.

\section{DISCUSSION}

\section{Pigmentation, absorption, and productivity}

Despite some differences in selected xanthophylls, the overall pigmentation of the diatom was the same when grown under equal irradiances of WL or BG light. The cellular absorption of both diatom cultures was essentially the same over most of the visible spectrum, with the exception of the notable enrichment of the near-UV light absorption in the WL cells (Fig. 2). This difference in the near-UV is most likely a reflection of the accumulation of photoprotectants in WL culture. A portion of the discrepancy could be attributed to the enrichment of the photoprotective yellow xanthophyll diadinoxanthin, while the remainder is presumably due to water-soluble photo-protective compounds not resolved by HPLC analysis.

These results suggest that light-limited populations of Chaetoceros gracile do not display large chromatic effects in cell pigmentation. Early work suggested chromatic adaptation of pigmentation in diatoms (Vesk \& Jeffrey 1977) while more recent studies do not (Humphrey 1983, Holdsworth 1985). These later studies suggest that the WL cultures of Vesk \& Jeffrey (1977) were nutritionally stressed (Humphrey 1983) and the lack of synthetic capabilities led to low WL pigment values (Holdsworth 1985). Perry et al. (1981) demonstrated that cells of $C$. gracile respond to lower light levels by increasing the size of their photosynthetic unit (PSU). These results suggest $C$. gracile pigmentation is photoregulated by light intensity and not light quality. We did, however, document chromatic regulation of the relative quantum yield and photosynthetic rate in $C$. gracile. BG $\alpha$ values were $44 \%$ higher than for WL cells. This observation can be interpreted either as a suppression of $\alpha$ in WL and/or an increase of $\alpha$ in BG light; unfortunately this cannot be resolved in this study. The cultures were light-limited and the higher $\alpha$ values in $B G$ cells led to higher photosynthetic rates. The increase in photosynthetic rates within the $B G$ culture explained the elevated growth rates. Other studies have also demonstrated that at low light intensities diatoms grown under BG light exhibit higher photosynthetic rates then cells grown under WL (Jeffrey \& Vesk 1977, Holdsworth 1985).

In the coccolithophorid Emiliania huxleyi, the pigment content of WL cells was twice that of BG cells. At the same time the pigment:chl a ratios for all pigments except $\beta, \beta$-carotene were identical for both cultures (Table 1). $\beta, \beta$-carotene is mostly localized within the reaction centers of photosynthesis (cf. Prézelin \& Boczar 1986) and its constancy suggests that the relative number of phototraps did not change with the quality of the growth illumination. It would appear that this phytoplankton species exhibited a chromatic adaptation strategy based on changing photosynthetic unit (PSU) size, i. e. where the relative amounts of lightharvesting accessory pigments per photosynthetic phototrap is regulated by the light environment of the cell (cf. Richardson et al. 1983). This simple explanation, however, is not entirely consistent with the documented changes in P-I parameters for WL vs BG grown cultures. It is likely that part of discrepancy is attributable to the fact that the BG culture was responding to light-limiting irradiances while the WL culture was responding to light-saturating irradiances for photosynthesis. Thus photophysiological differences between our cultures reflected photoadaptive responses to both irradiance and light quality (cf. Prézelin 1981, Prézelin \& Boczar 1986). 
While the diatom and coccolithophorid are both chl c-containing phytoplankton (= chromophyte), their accessory pigmentation differs significantly. The diatom Chaetoceros gracile possesses chl $C_{1+2}$ and photosynthetically active fucoxanthin. These pigments display in vivo absorption maxima near $460 \mathrm{~nm}$ and 490 to $520 \mathrm{~nm}$ respectively. Emiliania huxleyi differs from C. gracile in that it (1) lacks chl $c_{1 i}$ (2) contains a novel polar chl c-like pigment (chl c 3 i Jeffrey \& Wright 1987 , Fookes \& Jeffrey 1989); and (3) has 19' -hexanoyloxyfucoxanthin as its primary photosynthetically active xanthophyll (Haxo 1985, Jeffrey \& Wright 1987. Wright \& Jeffrey 1987). In addition improved HPLC separations have recently revealed that $E$. huxleyi contains non-polar chl $c$-related compounds which are distinguishable by its chromatographic behavior and spectral properties (Nelson \& Wakeham 1989).

The in vivo absorption properties of these novel $\mathrm{chl} C$ like compounds are poorly understood. However, since the blue Soret band of $\mathrm{chl}_{3}$ is hyperchromatically shifted by about $10 \mathrm{~nm}$ with respect to chl $c_{2}$ in acetone, we would also expect its in vivo absorption maximum to be shifted to about $470 \mathrm{~nm}$. Evidence for this shift can be seen by comparing the absorption and PSII transfer efficiency spectra measured for Chaetoceros gracile and Emiliania huxleyi. In both types of spectra measured for E. huxleyi, a prominent peak is observed near 470 to 475 $\mathrm{nm}_{i}$ this feature is absent in the $C$. gracile spectra. Differences in the PSII transfer effeciencies between 550 and $650 \mathrm{~nm}$ probably result from the chl c-like compounds present in E. huxleyi and, may account for the greater photosynthetic efficiencies and enhancement effects observed in the $475 \mathrm{~nm}$ waveband (Fig. 3). The present data are not sufficient to assess the influence of $19^{\prime}$-hexanoyloxyfucoxanthin on the spectral absorption and photosynthetic properties of E. huxleyi. It is, however consistent with known spectral characteristics of this carotenoid (Haxo 1985) to expect that the $10 \mathrm{~nm}$ shift in PSII transfer efficiency between 500 and $550 \mathrm{~nm}$ was caused by $19^{\prime}$-hexanoyloxfucoxanthin. The pigment-related shifts in PSII transfer efficiencies toward the wavelengths of light which penetrate deepest in the watercolumn (around $490 \mathrm{~nm}$ ) are also consistent with the extended depth distributions for prymnesiophytes in the open ocean (Bidigare et al. 1990, Ondrusek et al. 1989).

\section{Photosynthesis and bio-optical production models}

Bio-optical models which estimate primary production rates from spectral irradiance and water column pigment distributions spectra can be accurate to within $20 \%$ of measured production over a variety of time and space scales (Smith et al. 1990). In this study production calculated with the theoretical maximum value for quantum yield (i. e. 0.1 mole C Ein ${ }^{-1}$ ) gave values 2- to 3 -fold higher than those estimated via P-I relationships. This discrepancy is not surprising given that the measured values of $\phi(\lambda)$ in the blue to green region of the light field (400 to 550) were much lower than the theoretical maximum. Lewis et al. (1988) suggested that low $\phi(\lambda)$ in the blue-green wavebands could be caused by (1) absorption of light by photosynthetically incompetent chromophores or (2) a light energy imbalance between PSI and PSII. As in a recent study of Synechococcus (Boucher et al. unpubl.), the present study documents the importance of restricted Emerson enhancement effects in chromophytes. Our results suggest that enhancement effects may be significant in natural light fields where proportionally more bluegreen light is absorbed by chl and accessory pigments. Furthermore the presence of photoprotective pigments (diadinoxanthin) could partially explain the low quantum yield measured at the blue-green wavelengths as was shown to be the case for zeaxanthin in Synechococcus (Bidigare et al. 1989).

${ }^{14} \mathrm{C}$-based photosynthesis measurements are labor intensive, expensive, and not amenable to mooring applications. Neori et al. (1988) suggested that room temperature fluorescence excitation spectra provide an alternative to oxygen action spectra in assessing the photosynthetic potential of PSII. The spectral quantum yield $\phi(\lambda)$ derived from carbon action spectra represents the net activity of both photosystems and its general shape was found to be similar to the quantum yield of PSII fluorescence. A comparison of the shapes of PSII fluorescence yield and $\phi(\lambda)$ reveals that PSII fluorescence yield is lower at the blue-green wavelengths where enhancement effects were greatest. Enhancement effects would not be observed in the fluorescence excitation spectrum which is an index of PSII activity. As a first approximation, however, the fluorescence excitation spectra may provide a proxy estimate of $\phi(\lambda)$ and represents an approach which could be adapted to moorings.

In conclusion, algal clones responded to the spectral quality of the growth irradiance by either increasing photoprotective pigments or increasing PSU size. Changes in cellular pigmentation drove the changes in absorption and carbon fixation. Significant enhancement effects in the blue-green wavebands resulted in 17 to $36 \%$ increases in carbon fixation rates, and further studies are required to assess the importance of enhancement effects over a variety of size and spectral classes of algae. Productivity rates predicted by the biooptical model were in good agreement with measured production (P-I curves and enhanced C-action spectra) provided there was information of the light field and that measured $\phi(\lambda)$ averaged over PAR was used. To 
increase the accuracy of the current model for field application, future investigations should focus on the factors affecting quantum yield and a reliable means of predicting in situ variations of this critical parameter.

Acknowledgements. This manuscript is dedicated to the memory of B. M. Sweeney. This research was supported by Watercolors 88, NSF grants OCE 88-00099 (B.B.P.) and OCE 88-13727 (R.R.B.) and ONR contract N00014-86-C-0379 (R.R.B.). Special thanks are given to Norman Nelson for measuring the spectral outputs of the lamps and filters and John T. Kirk for helpful discussion. Watercolors contribution No. 5 and Biowatt contribution No. 41.

\section{LITERATURE CITED}

Bidigare, R. R. (1989). Photosynthetic pigment composition of the brown tide alga: unique chlorophyll and carotenoid derivatives. In: Cosper, E., Carpenter, E. J., Bricelj, M. (eds.) Coastal and estuarine studies, Vol, 35. SpringerVerlag, Berlin p. 57-75

Bidigare, R. R., Marra, J, Dickey, T. D., Iturriaga, R., Baker, K. S., Smith, R. C., Pak, H. (1990). Evidence for phytoplankton succession and chromatic adaption in the Sargasso Sea during spring 1985. Mar. Ecol. Prog. Ser. 60: 122

Bidigare, R. R., Schofield, O, Prézelin, B. B. (1989). Influence of zeaxanthin on quantum yield of photosynthesis of Synechococcus clone WH7803 (DC2). Mar. Ecol. Prog. Ser 56: $177-188$

Bidigare, R. R., Smith, R. C., Baker, K. S., Marra, J. (1987). Oceanic primary production estimates from measurements of spectral irradiance and pigment concentration. Biogeochem. Cycles 1: 171-186

Bricaud, A., Morel, A., Prieur, L. (1983). Optical efficiency factors of some phytoplankters. Limnol. Oceanogr. 28: 816-832

Caceci, M. S., Cacheris, W. P. (1984). Fitting curves to data. Byte 9: 340-362

Emerson, R., Lewis, C. M. (1942). The photosynthetic efficiency of phycocyanin in Chroococcus and the problem of caroteniod participation in photosynthesis. J. gen. Physiol. 25: 579-595

Fookes, C. J. R., Jeffrey, S. W. (1989). The structure of chlorophyll $c 3$, a novel marine photosynthetic pigment. Chem. Communs. 23: 1827-1828

Guillard, R. R., Ryther, J. H. (1962). Studies of marine phytoplankton diatoms. I. Cyclotella nana Husdet and Detonula confervacea Gran Can. J. Microbiol. 8: 229-239

Haxo, F. T (1985). Photosynthetic action spectrum of the coccolithophorrid, Emiliania huxleyi (Haptophyceae): 19 hexanoyloxyfucoxanthin as antenna pigment. J. Phycol. 21: 282-287

Holdsworth, E. S. (1985). Effect of growth factors and light quality on the growth, pigmentation and photosyntheisi of two diatoms. Thalassiosira gravida and Phaeodactylum tricornutum. Mar. Biol. 86: 253-262

Humphrey, G. F. (1983). The effect of the spectral composition of light on the growth, pigments, and photosynthetic rate of unicellular marine algae J. exp. mar. Biol. Ecol. 66: $49-67$

Jeffrey, S. W., Vesk, M. (1977). Effect of blue-green light on photosynthetic pigments and chloroplast structure in the marine diatom Stephanopyxis turnis. J. Phycol. 13: 271-279

Jeffrey, S. W., Wright, S. W. (1987). A new spectrally distinct component in preparations of chlorophyll $c$ from microalga Emiliania huxleyi (Prymnesiophyceae). Biochim. Biophys. Acta 894: 180-189

Kiefer, D. A., Mitchell, G. B. (1983). A simple steady state description of phytoplankton growth based on absorption cross section and quantum efficiency. Limnol. Oceanogr. 28: 770-776

Kovala, P. E., Larrance, J. D. (1966). Computation of phytoplankton cell numbers, cell volume, cell surface and plasma volume per liter, from microscopical counts. Univ. of Washington Dept of Oceanography Spec. Rep. 38, reference M66-41

Lewis, M. R., Warnock, R. E., Platt, T (1985). Measuring photosynthetic action spectra of natural phytoplankton populations. J. Phycol. 21: 310-315

Lewis, M. R., Ulloa, O., Platt, T (1988). Photosynthetic action absorption, and quantum yield spectra for a natural population of Oscillatoria in the North Atlantic Limnol. Oceanogr. 33: 92-99

Morel, A., Bricaud, A. (1986). Inherent optical properties of algal cells including phytoplankton: theoretical and experimental results. In: Platt, T., Li, W. K. (eds.) Photosynthetic picoplankton. Can. Bull. Fish. Aquat. Sci. 214: $521-559$

Morel, A., Lazzara, L., Gostan, J. (1987). Growth rate for a diatom to changing irradiances (energy and color). Limnol. Oceanogr. 32: 1066-1084

Nelson, J. R., Wakeham, S. G. (1989). A phytol-subsittuted chlorophyll $c$ from Emiliania huxleyi (Prymnesiophyceae). J. Phycol. 25: 761-766

Neori, A., Vernet, M., Holm-Hansen, O., Haxo, F. T (1988) Comparison of chlorophyll far-red and red fluorescence exitation spectra with photosynthetic oxygen action spectra for photosystem II in algae. Mar. Ecol. Prog. Ser. 44: 297--302

Ondrusek, M. E., Bidigare, R. R., Sweet, S. T., DeFreitas, D. A., Brooks, J. M. (1990). Distribution of algal pigments in the North Pacific Ocean in relation to physical and optical veriability. M. S. thesis, Dept of Oceanography, Texas A \& $M$ University

Perry, M. J., Talbot, M. C., Alberte, R. S. (1981). Photoadaptation in marine phytoplankton: response on the photosynthetic unit. Mar. Biol. 62: 91-101

Prézelin, B. B. (1981). A review: light reactions in photosynthesis. In: Platt, T. (ed.) Proc. NATO Advanced Study Institute: physiological ecology of phytoplankton. Can. Bull. Fish. Aquat. Sci. 210: 1-43

Prézelin, B. B., Baker, K. S., Bidigare, R. R., Smith, R. C. (1988). Bio-optical modeling of a coastal front. XIX General Assembly, IUGG-IAPSO p. 1702

Prézelin, B. B., Boczar, B. A. (1986). Molecular bases of cell absorption and fluorescence in phytoplankton: potential applications to studies in optical oceanography. Prog. Phycol Res. 4: 350-464

Prézelin, B. B., Glover, H. E., Ver Hoven, B. M., Steinberg, D., Matlick, H. A., Schofield, O., Nelson, N. B., Wyman, M. Campball, L. (1989). Blue-green light effects on lightlimited rates of photosynthesis: relationship to pigmentation and productivity estimates for Synechococcus populations from the Sargasso Sea. Mar. Ecol. Prog. Ser. 54: $121-136$

Reid, A., Hessenberg, B., Metzier, H., Ziegler, R. (1977). Distribution of excitation energy among photosystem I and photosystem II in red algae. I. Action spectra of light reactions I and II. Biochim. Biophys. Acta. 459: 175-186

Richardson, K., Beardall, J., Ravens, J. (1983). Adaptation of unicellular algae to irradiance: an analysis of strategies. New Phytol. 93: 157-191 
Smith, R. C., Bidigare, R. R., Prézelin, B. B., Baker, K. S., Brooks, J. M. (1987). Optical characterization of primary productivity across a coastal front. Mar. Biol. 96: 575-591 Smith, R. C., Prézelin, B. B., Bidigare, R. R., Baker, K. S. (1990). Bio-optical modeling of photosynthetic production. Limnol. Oceanogr. 34: 1526-1546

Strickland, J. D. H., Parsons, T. R. (1972). A practical handbook of seawater analysis, 2nd edn. Bull. Fish. Res. Bd Can. 167

Vesk, M., Jeffrey, S. W. (1977). Effect of blue-green light on

This article was submitted to the editor photosynthetic pigments and chloroplast structure in unicellular marine algae from six classes. J. Phycol. 13: 280-288

Wright, S. W., Jeffrey, S. W. (1987). Fucoxanthin pigment markers in marine phytoplankton analyzed by HPLC and HPTLC. Mar Ecol. Ser. 38: 259-266

Zimmerman, R. C., Soohoo, J. B., Kremer, J. N., D'Argenio, D. Z. (1987). Evaluation of variance approximation techniques for non-linear photosynthesis-irradiance models. Mar. Biol. 95: 209-215

Manuscript first received: October 30, 1989 Revised version accepted: March 23, 1990 